\title{
Lignin-cellulosic biomass delignification for methylated alcohol production
}

\section{Mykola Sychevsky, Sergiy Oliynychuk}

\section{Institute of Food Resources of National Academy of Agrarian Sciences of Ukraine, Kyiv, Ukraine}

\section{Keywords:}

Alcohol

Cellulose

Biomass

Solvent

Lignin

\section{Article history:}

Received 22.02.2019

Received in revised form 14.07.2019

Accepted 30.09.2019

\section{Corresponding author:}

Sergiy Oliynychuk

E-mail:

oliynichukst@ukr.net

DOI: $10.24263 / 2304-$

974X-2019-8-3-7

\section{Abstract}

Introduction. Sugar's molecules of lignin-cellulosic biomass make them inaccessible for carrying-out of polysaccharose depolymerization. The aim of investigation is power of physical-chemical parameters on the process of organosolv delignification of lignin-cellulosic biomass.

Materials and methods. Target of research is the way of organosolv lignin dilution. As a raw stuff we used a wheat straw, afterharvesting maize shruffs and halm of sugar broomcorn. Lignin was determined by the hydrolysis of mixed of concentrate hydrochloric acid and $72 \%$ sulphuric acid, polysaccharides - in amount of monosaccharide by the Machen and Schoorl method.

Results and discussion. For maximum lignin dilution a solvent composition, fineness degree of row, treatment temperature and a process time were investigated. Depending on concentration change of sulphuric acid (from 1 to $3,9 \%$ ) in solvent, lignin yield from maize'chaff is increased from 14,4 to $29,2 \%$, content of undissolved remainder is decreased from 66,7 to $55,4 \%$. The lignin yield is changed from 19,3 to $32,4 \%$ in stalk of sugar sorghum in the same condition. Treatment temperature rising of chopped wheat straw from 70 to $100{ }^{\circ} \mathrm{C}$ contributed to an increase in the degree of conversion of lignin by $3 \%$, and for the stalks of corn - this indicator changed from $6.8 \%$ to $17.1 \%$. Maximum lignin dissolution is at the temperature of $100 \mathrm{C}^{\circ}$, wherein the highest yield of reducing substances is achieved within 1:00, regardless of the type of plant material. Lignin conversion increases at increase processing time to $6: 00$, but at the same time there is a destruction of sugar molecules, the content of which is almost halved.

Conclusions. The hydrolysis degree of lignin by an organosolvent solvent can be adjusted by choosing rational modes of grinding of raw materials, temperature and duration of the process. 


\section{Introduction}

However the global trend is a significant incline in the production of bioethanol, a decrease in its cost, and an increase in competitiveness basing with the use of non-food raw materials, in particular, lignocellulosic biomass.

Bioconversion of renewable materials to ethanol considered as one of the key branches of biotechnology [1].

\section{Literature review}

Lignin- cellulose transformation into etanol for sugar's releasing from biomass and their hydrolysis by ferments to distiller's monosugar [2]. Cellulose and hemicellulose contain sugars in polymeric form and can be hydrolyzed by enzymes to fermented monosaccharides for further fermentation into bioethanol. The barrier to cellulose hydrolysis is lignin, which protects it from chemical reagents, microbial and enzyme attacks [3]. Therefore, in order to increase the availability of cellulose and hemicellulose to hydrolysis, the cellular structure of plant biomass must be destroyed by breaking their chemical bonds with lignin.

There is a wide range of methods for the pretreatment of cellulose-containing raw materials, the said methods being divided into four types according to the nature of their impact: physical, mechanical, chemical and biological. Physical methods are the treatment with $\gamma$-rays or a stream of electrons, processing with microwave radiation $(2400-2500 \mathrm{MHz}$ ), heating in air or in an atmosphere of $\mathrm{CO}_{2}\left(100^{\circ} \mathrm{C}\right)$, in water or in a gas, cooling, processing under elevated or reduced pressure, action of ultrasound [4-8]. The structure of cellulose is also destroyed when it is heated beyond the elevated pressure [9]. Processing methods increase the reactivity of cellulosic raw materials by $2-5$ times [10].

Mechanical methods of pretreatment of cellulose-containing raw materials (CCRM) consist in their grinding in various types of mills (ball, colloid, and vibration), disintegrators and crushers, dispersing on rollers, etc. CCRM are ground both in dry and in wet form [9]. The use of mechanical methods leads to the destruction of the crystal structure of cellulose, an increase in the surface available for cellulolytic enzymes and, as a result, a significant increase in the reactivity of CCRM (10 or more times) $[10,11,12]$.

Chemical pretreatment methods are based on the ability of certain chemical compounds to dissolve lignin or cellulose, or lead to swelling and destruction of its structure. When such solutions are diluted with water, acetone or alcohol, precipitation (regeneration) of cellulose occurs. Regenerated cellulose is practically amorphous, and if regeneration is not carried out in an aqueous medium, this significantly increases the specific surface area of the regenerated cellulose.

Cellulose swelling, dissolution and amorphization are also occurring in solutions of inorganic salts, accompanied by mercerization (swelling and rearrangement of the structure) and amorphization of cellulose [13].

Pretreatment methods with $0.2 \% \mathrm{H}_{2} \mathrm{SO}_{4}$ at $180{ }^{\circ} \mathrm{C}$ for $30 \mathrm{~s}$ and $0.1 \%$ at $180{ }^{\circ} \mathrm{C}$ for 45 minutes are described [14]. The hydrolysis of cellulose under these conditions is insignificant, but the degree of polymerization and the crystallization index decrease, there is also a substantial hydrolysis of hemicellulose. Delignification of cellulosic raw materials with ammonia with hydrogen peroxide, peracetic acid, a mixture of $99.9 \%$ acetic anhydride and $30 \%$ hydrogen peroxide $(1: 1)$ at $80{ }^{\circ} \mathrm{C}$ is also described [15]. 
Research and development of numerous methods of delignification of lignin-cellulosic biomass testify to the urgency of the problem of its use for the production of cellulose as a raw material in biotechnological and chemical processes.

The above methods of delignification have their advantages and disadvantages, in particular low efficiency, multi-stage technological process and negative impact on environmental safety.

Recently, intensive research and development has been carried out to improve the known methods and to develop new ones for the preliminary preparation of lignocellulose biomass for its hydrolysis. One of the modern trends is the implementation of steam technology by saturating the crushed mass within a few minutes with high-pressure steam at a temperature about $200{ }^{\circ} \mathrm{C}$, followed by an instantaneous decrease in pressure [US Patent No. 4461648 Delignification steam, unauthorized slightly acid and enzymatic hydrolysis, Canada Patent No. 1287705 Continuous process bioethanol production from lignin-cellulosic biomass using continuous steam production technology and auto hydrolysis]. Under such conditions, the lignin-cellulose matrix is destroyed.

There are data $[16,17]$ on new organosolv cellulose extraction methods based on the ability of organic solvents (acetone, ethanol, methanol, etc.) to dissolve lignin and hemicellulose under certain conditions by depolymerizing molecules and their fragments. After dissolving lignin and hemicellulose, these reagents make cellulose available for the action of catalysts or enzymes. Thus, the pretreatment of plant materials is just the destruction of lignin. A feature of the chemical reactions of this process is that these are heterogeneous reactions of high-molecular compounds, the intensity of which depends on the availability of the reaction centers in the polymer structure. Among organosolv solvents for organic solution methods of delignification of lignin-cellulose biomass, ethyl alcohol, in the form of bioethanol as the final product of biomass processing, is the most accepTable by technological, economic and environmental indicators $[18,19]$.

Ethanol production with previous biomass structure destruction by organosolvent method was implemented by Biogabol (Denmark) at the pilot plant level, by Amerikan Process Inc. (USA) implemented an industrial installation in a pulp and paper mill.

Taking into account the peculiarities of ethanol production, varieties of vegetable raw materials and its processing, the study of the influence of the parameters and composition of the solvent on the course of the hydrolysis process is relevant.

So, the purpose and objectives of the study are to develop scientific and methodological foundations of organosolv delignification of lignin-cellulosic biomass for the production of second-generation bioethanol.

According to the goal, the ratio of the components of an organosolv solvent to the degree of delignification of wheat straw, post-harvest corn waste, and dried sorghum stalk was determined; the influence of temperature and pressure, the degree of grinding of raw materials and treatment duration on the process of delignification was investigated.

\section{Materials and methods}

\section{Materials}

In research, raw materials for delignification wheat straw, post-harvest corn waste and dried sorghum (Mohawk variety) stalk were used as raw materials. The chemical composition of the raw materials is given in Table 1 . 
Chemical composition of raw materials for delignification

\begin{tabular}{|l|c|c|c|}
\hline \multirow{2}{*}{ Parameter } & \multicolumn{3}{c|}{ Raw material } \\
\cline { 2 - 4 } & Wheat straw & $\begin{array}{c}\text { Post-harvest corn } \\
\text { waste }\end{array}$ & $\begin{array}{c}\text { Dried stalk of } \\
\text { sugar sorghum }\end{array}$ \\
\hline Cellulose & 34.6 & 30.5 & 26.1 \\
\hline Hemicellulose & 23.8 & 31.9 & 34.4 \\
\hline Lignin & 25.0 & 24.0 & 15.6 \\
\hline Ash & 5.0 & 2.3 & 2.8 \\
\hline Ballast substances & 11.6 & 11.3 & 21.1 \\
\hline
\end{tabular}

As it can be seen from Table 1, the waste of corn and the stalk of sugar sorghum compared with wheat straw are characterized by lower cellulose content by $4.5 \%$ and $9.5 \%$, respectively. In addition, they are distinguished by a high content of hemicellulose (by $8.1 \%$ for corn stalk and by $9.6 \%$ for sugar sorghum stalks), which is easily hydrolyzed to form reducing sugars.

The content of ballast substances in the stalk of sugar sorghum is almost two times higher compared to wheat straw and post-harvest corn waste. Such substances include pectincontaining gums and other compounds not applicable for the production of ethanol [1].

Since the lignin content in the stalk of sugar sorghum is rather low, it is hypothetically possible to predict a high yield of sugars suiTable for fermentation into ethanol [2].

\section{Preparation of prototypes}

To release the plant mass from the lignin, it was ground to a particle size of $1-3 \mathrm{~cm}$, mixed with a solvent in a ratio of 1:4, the composition of which had 50\% ethyl alcohol, $47 \%$ water and $3 \%$ of normal sulfuric acid, carried out delignification in a sealed autoclave at temperature 100-150 oC and excess pressure 0.25-0.3 MPa.

Procedure for conducting research.

The prepared reaction mixture with dissolved lignin was separated by filtration. The lignin-free solid phase was used for hydrolysis to the fermented sugars by cellulolytic enzymes, and the solvent was removed from the liquid fraction by the method of distillation. Under these conditions, lignin precipitates and after drying can be used as a end product.

\section{Research methods}

- The moisture content of cellulosic raw materials was determined by drying to constant weight at a temperature of $100-105{ }^{\circ} \mathrm{C}$;

- Lignin content - by direct method by hydrolysis with a mixture of concentrated hydrochloric acid and $72 \%$ sulfuric acid [20];

- The amount of polysaccharides, easily and difficultly hydrolyzed, was determined by the number of monosaccharides by reducing ability determined by the MaquenneSchoorl method [20]. 


\section{Results and discussion}

\section{Effect of solvent composition on the yield of lignin and reducing sugars}

In the technology of organosolv delignification of vegetable raw materials, the composition of the solvent is an important factor that affects the intensity, completeness and course of the dissolution of lignin $[16,17]$. As a result of experimental studies, it was observed that the ratio of the components of the solvent, in particular, the content of sulfuric acid, has a certain effect on the release of lignin [21]. In experiments with delignification of the fine ground wheat straw (Figure 1) an increase in the concentration of sulfuric acid in the mixture volume in the range of $1.0-3.9 \%$ by volume contributed to a higher yield of lignin from $14.4 \%$ to $29.2 \%$ and the transition of easily hydrolyzed polysaccharides into solution. The amount of reducing substances in the filtrate was $30.2 \%$ more compared to the lower acid content. In the case, deeper destruction of the raw material polymers and a decrease in the undissolved residue from 66.7 to $55.4 \%$ in terms of absolutely dry matter (ADM) of the analyzed samples occurs.

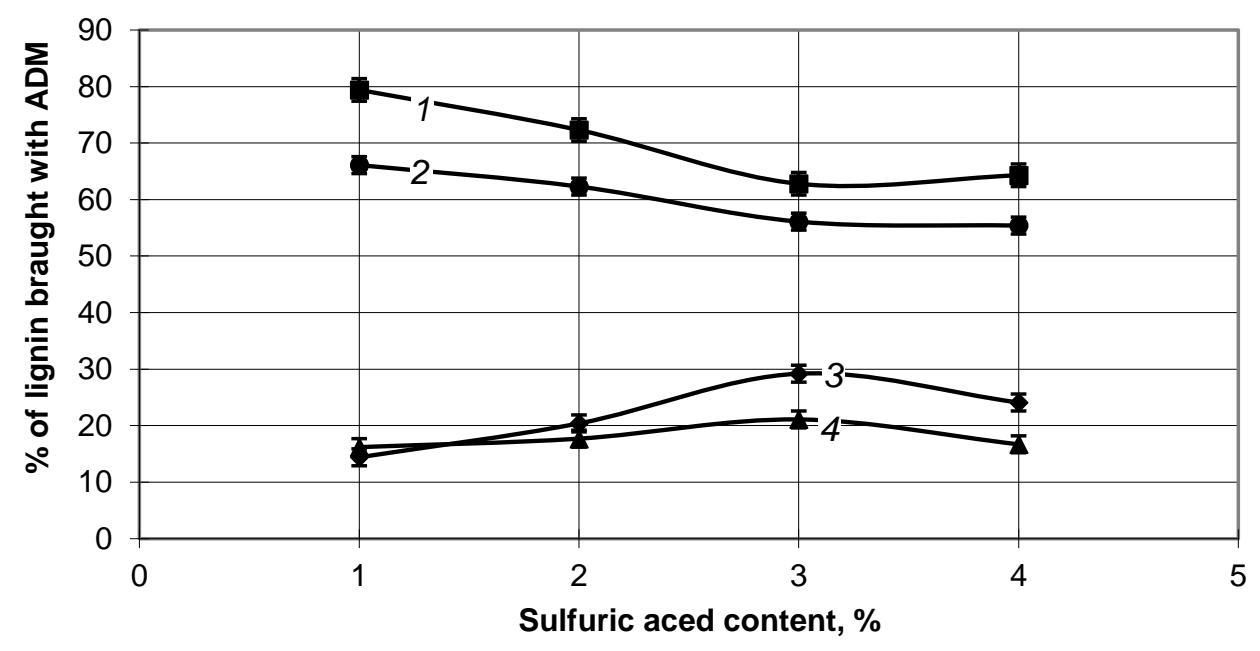

Figure 1. Effect of solvent components ratio on the yield of lignin and reducing sugars from wheat straw:

1 - Content of residual lignin, \% of primary lignin brought with ADM;

2 - Conversion grade of lignin, \% of primary lignin brought with ADM;

3 - Conversion of reducing substances, \% of brought ADM;

4 - Yield of solid residue, \% of brought ADM

The same pattern of influence of the acid content on the conversion of lignin and reducing substances continued in the experiments of delignification of the stalks of sugar sorghum (Figure 2). The increase in the amount of acid in the solvent contributed to a more complete release of lignin (from 19.3 to $32.4 \%$ ). This is because the increase in the amount of sulfuric acid in the solvent, which is a catalyst for the polysaccharide hydrolysis reaction and in aqueous solutions, dissociates into the hydroxonium $(\mathrm{H} 3 \mathrm{O}+)$ ion, which protects the glycosides' bond. As a result, acetyl oxygen goes into a 4-valent state, the stability of the glycosides' bond decreases, and it splits with the formation of two parts of macromolecules. 
The final reaction product is monosaccharide's [1]. The grade of lignin conversion of the stalks of sugar sorghum was higher compared to the ground wheat straw, the possible explanation of the fact being a lower crystallinity index of sorghum cellulose [21].

Analyzing the parameters studied, we can conclude that for the delignification of the grinding of wheat straw, sorghum stalks and maize the most effective is the use of a wateralcohol oxidizer, which containing $3 \%$ (by volume) of sulfuric acid as a catalyst.

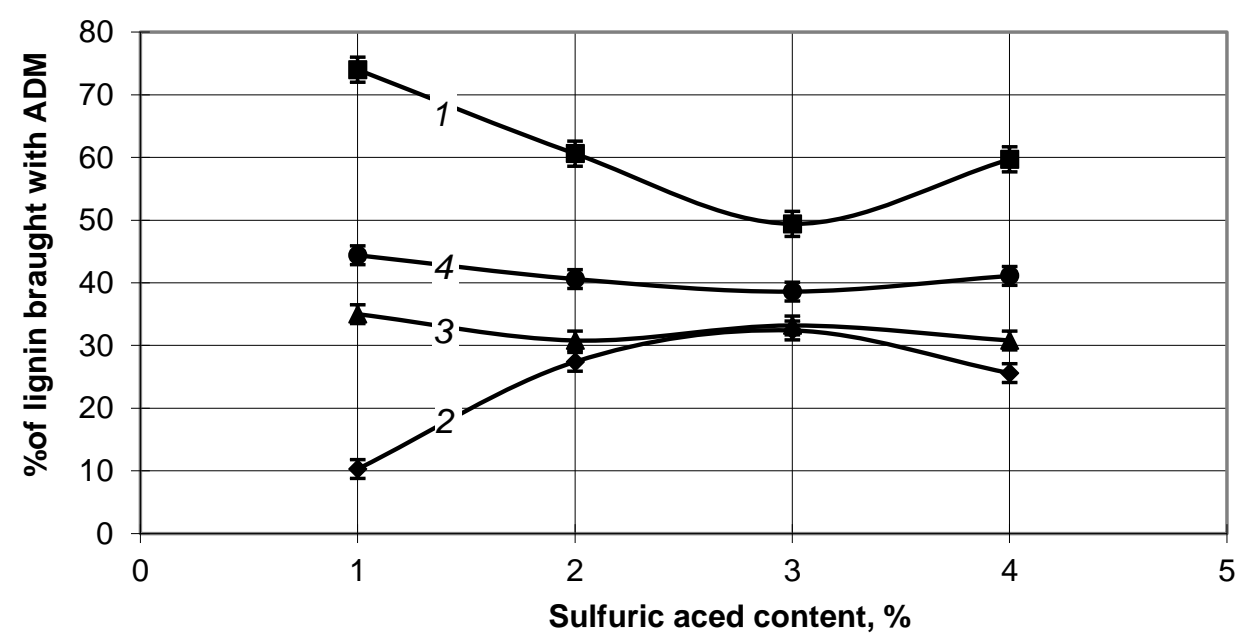

Figure 2. Effect of the ratio of solvent components on the yield of lignin and reducing sugars from the stalk of sugar sorghum:

1 - Content of residual lignin, \% of primary lignin brought with ADM;

2 - Conversion grade of lignin, \% of primary lignin brought with ADM;

3 - Conversion of reducing substances, $\%$ of brought ADM;

4 - Yield of solid residue, \% of brought ADM

\section{Treatment temperature influence of vegetable raw materials on the lignin yield}

Based on the supramolecular structure of the cellulose and the presence of amorphous and crystalline fractions, it can be assumed that the increase in temperature promotes the penetration of the catalyst into amorphous regions, where it acts on all macromolecule bonds, which accelerates the hydrolysis of lignin-cellulose biomass.

Data characterizing the degree of bioconversion of lignin from the grinding of wheat straw are given in Table 2, and from the stalks of corn in Table 3.

Effect of processing temperature on the yield of lignin from wheat straw

Table 2

\begin{tabular}{|l|c|c|c|c|}
\hline \multirow{2}{*}{\multicolumn{1}{|c|}{ Parameter }} & \multicolumn{4}{|c|}{ Temperature during dwell time, ${ }^{\circ} \mathbf{C}$} \\
\cline { 2 - 5 } & $\mathbf{7 0}$ & $\mathbf{8 0}$ & $\mathbf{9 0}$ & $\mathbf{1 0 0}$ \\
\hline Lignin content in sample weight, g & 4.65 & 4.65 & 4.65 & 4.65 \\
\hline Yield of solid residue, \% & 63.7 & 62.3 & 61.6 & 60.9 \\
\hline Conversion grade of lignin, \% & 26.0 & 26.3 & 26.5 & 29,3 \\
\hline Residual lignin content, \% of ADM & 74.0 & 73.7 & 73.5 & 70.7 \\
\hline
\end{tabular}


From Table 2 it can be seen that with an increase in the processing temperature of ground straw, the yield of solid sediment decreases to $60.9 \%$, while the residual lignin content decreases to $70.7 \%$, that is that the temperature can be considered to rise, the hydrolysis of the carbohydrate part of the straw to increase, and selectivity and degree of lignin conversion to incline up to $29.3 \%$.

Table 3

Effect of processing temperature on the yield of lignin from ground corn stalk

\begin{tabular}{|l|c|c|c|c|}
\hline \multirow{2}{*}{ Parameter } & \multicolumn{4}{|c|}{ Temperature during dwell time, ${ }^{\circ} \mathbf{C}$} \\
\cline { 2 - 5 } & $\mathbf{7 0}$ & $\mathbf{8 0}$ & $\mathbf{9 0}$ & $\mathbf{1 0 0}$ \\
\hline Lignin content in sample weight, g & 4.39 & 4.39 & 4.39 & 4.39 \\
\hline Yield of solid residue, \% & 68.6 & 66.8 & 52.8 & 48.3 \\
\hline Conversion grade of lignin, \% & 1.8 & 9.1 & 13.0 & 13.7 \\
\hline Residual lignin content, \% of ADM & 98.2 & 90.9 & 87.0 & 86.3 \\
\hline
\end{tabular}

Other results were obtained when delignifying corn stalks, where the yield of solid residue was significantly lower than that from wheat straw, it was $48.3 \%$, but the lignin conversion grade was also significantly less $-13.7 \%$ (Table 3 ). This can be explained by the fact that the decrease in the yield of solid residue is due to a higher content of easily hydrolytic polysaccharides, in particular hemicelluloses [22]. At the same time, the lignin conversion grade was almost two times less compared to that of wheat straw, being in our opinion due to the degree of grinding $[18,19]$.

Pre-grinding of raw materials increases the specific surface area and reduces the degree of polymerization of the cellulose substrate, while reducing the crystallinity index [19]. The combination of these factors positively affects the reactivity of the cellulose substrate [23].

To confirm or refute this conclusion, a study was conducted on the processing of corn stalks, ground in a laboratory mill (Table 4).

Effect of grinding on the conversion of lignin with corn stalks

Table 4

\begin{tabular}{|l|c|c|c|c|}
\hline \multirow{2}{*}{ Parameter } & \multicolumn{4}{|c|}{ Temperature during dwell time, ${ }^{\circ} \mathbf{C}$} \\
\cline { 2 - 5 } & $\mathbf{7 0}$ & $\mathbf{8 0}$ & $\mathbf{9 0}$ & $\mathbf{1 0 0}$ \\
\hline Lignin content in sample weight, $\mathrm{g}$ & 4.39 & 4.39 & 4.39 & 4.39 \\
\hline Yield of solid residue, \% & 63.3 & 57.1 & 50.4 & 44.1 \\
\hline Conversion grade of lignin, \% & 6.8 & 9.3 & 15.7 & 17,1 \\
\hline
\end{tabular}

The data of Table 4 confirm the conclusion about the impact of the degree of grinding on the delignification of raw materials, the conversion of lignin increases significantly and reaches $17.1 \%$ at a temperature of $100{ }^{\circ} \mathrm{C}$.

\section{Influence of treatment duration on lignin-cellulosic biomass delignification}

The duration of the delignification process also affects the content of residual lignin, the degree of its conversion and the content of reducing substances, as the data in Table 5 confirm. 
Effect of processing time on delignification of wheat straw at a temperature $100{ }^{\circ} \mathrm{C}$

\begin{tabular}{|l|c|c|c|c|c|c|}
\hline \multirow{2}{*}{ Parameter } & \multicolumn{6}{|c|}{ Processing time, hours } \\
\cline { 2 - 7 } & $\mathbf{1}$ & $\mathbf{2}$ & $\mathbf{3}$ & $\mathbf{4}$ & $\mathbf{5}$ & $\mathbf{6}$ \\
\hline Yield of solid residue, \% & 57.3 & 55.7 & 53.1 & 52.6 & 51.8 & 50.0 \\
\hline Content of residual lignin, \% & 82.1 & 79.4 & 76.4 & 73.4 & 69.6 & 68.9 \\
\hline Lignin conversion grade, \% & 15.9 & 17.6 & 20.5 & 22.3 & 22.7 & 23.7 \\
\hline Content of reducing substances, \% & 24.3 & 16.9 & 14.1 & 12.5 & 11.5 & 10.7 \\
\hline
\end{tabular}

The data adduced show that at a constant temperature and an increase in processing time up to 6 hours, the yield of solid residue decreases to $50 \%$ of the initial mass of raw materials, the content of residual lignin in biomass decreases to $68.9 \%$, and the degree of lignin conversion increases to $23,7 \%$ of its content in the straw.

At the same time, with an increase in the duration of the process, the destruction of sugar molecules occurs, the number of which constantly decreases and amounts to $10.7 \%$ of processing for six hours versus $24.3 \%$ in the first hour of hydrolysis. Therefore, the most acceptable is the period of treatment for one hour stipulated with fine grinding $[16,17]$.

Thus, the promise of using a solvent of lignin based on ethyl alcohol is experimentally proven this making the process of hydrolysis of lignin-cellulosic biomass economically feasible. According to the results of research, an experimental regulation has been developed for the delignification of CCRM, as the first regulatory document for organizing the pilotindustrial production of bioethanol from starch-containing raw materials and CCRM.

\section{Conclusion}

1. The methodological basis for the delignification of CCRM with organosolv solvents using the example of wheat straw, corn stalks and sugar sorghum stalks is theoretically and experimentally substantiated.

2. Cellulosic biomass delignification is carried out by using a lignin solvent based on ethyl alcohol and sulfuric acid.

3. That according to the total conversion grade of cellulose-containing components of the raw materials into reducing substances, the most rational is the use of a solvent with a concentration of sulfuric acid of $3 \%$ (by volume) for wheat straw and corn stalks and $1 \%$ (by volume) for stalks of sorghum for the duration of the process within one and three hours.

4. The yield of the solid residue after the treatment of the raw material with an organosolv solvent decreases, and the degree of lignin conversion increases with increasing treatment temperature and the degree of biomass grinding.

\section{References}

1. Sushkova V.I.. Vorobeva T.I. (2007), Waste-free conversion of plant raw materials into biologically active substances, Kirov.

2. Tsyigankov S.P, Volodko O.I., Yemets A.I. (2013), Development and implementation of complex transformation technology of carbohydrate content of plant raw materials into bioethanol, Nauka ta inovaciyi, 9(4), pp. 55-59. 
3. Chang M., Chou T., Tsao G.T. (1981), Structure, pretreatment and hydrolysis of cellulose, Bioenergy, Ed. A. Fiechter, Berlin, Hiedelberg, New York, pp. 15-32.

4. Ghose T.K. (1977), Cellulase biosynthesis and hydrolysis of cellulose substances, $A d v$. Biochem. Eng., Berlin, Heildelberg, 6, pp. 39-48.

5. Linko M. (1977), Cellulose hydrolysis, Adv. Biochem. Eng., Berlin, Heidelberg, 5, pp. $27-$ 42.

6. Kitts W.D., Krishamurpi J.A., Shaltord J.A. et al (1969), Use of wood and woody byproducts as a source of energy in breef cattle rations, cellulases and their applications, Washington, pp. 279-297.

7. Kumakara M., Kojinm T., Kaetsu I. (1982), Pretreatment of ligninocellulosic wastes by combination of irradiation and mechanical crashing, Biomass., 2, pp. 299-308.

8. Artur D. (1974), Reactions initiated by radiation of high energy, Tsellyuloza $i$ ee proizvodnyie, Moscow, 2, pp. 291-356.

9. Sinitsyn A.P., Klesov A.A. (1981) Effect of pre-treatment on effectiveness of fermentative conversion of the cotton linter, Prikladnaya biohimiya I mikrobiologiya, 17 (5), pp. 682695.

10. Sinitsyn A.P., Kovalev G.V., Messa-Mansera S.R. (1984), Comparative study of the effect of different methods of pre-treatment on the rate of fermentative hydrolysis of natural materials, Himiya drevesinyi, 5, pp. 60-71.

11. Kelsey R.G. Shafizadeh F. (1977), Enhancement of cellulose accessibility and enzymatic hydrolysis by simultaneous milling, Biotechnol. Bioeng., 19, pp. 1321-1329.

12. Vurasko N.V. et all (2007), Resource saving technology of obtaining cellulose by complex processing of rice straw, Himiya rastitelnogo syirya, 2, pp.21-25.

13. Cheropkina R.I., Kushmitko O.V., Chernyak A.M. (2012), Neutral sulfite delignification of rape straw, Himichna ingeneriya, ekologiya ta resursozberegennya, 1, pp. 1-5.

14. Antonenko L.P., Vasilchuk O.V., Kulikovskaya M.V., Siroshtan N.G. (2009), Low temperature oxidative delignification with hydrogen peroxide. Delignification of wheat straw, Energotehnologii i resursosberegenie, 2, pp. 39-43.

15. Kuznetsov B.N., Danilov V.T., Sudakova I.T. (2009), Delignification of whet straw with the mixture of acetic acid and hydrogen peroxide over sulfuric catalyst, Himiya rastitelnogo syirya, Krasnoyarsk, 4, pp. 5-8.

16. Cordeiro N. et all. (2002), The organosolv fractionation of cork components, Holzforschung, 56, pp. 135-142.

17. Brosse N., Sannigrahi P., Ragauskas N. (2009), Pretreatment of Miscantus Giganteus Using the Ethanol Organosolv Process for Ethanol Production, Ind. Eng. Chemistry Resources, 48, pp. 83-88.

18. Galimova A.R., Vurasko A.V.,Driker B.N. (2007), Cellulose production be oxidativeorganosolvent method by complex processing of annual plants, Novyie dostigheniya $v$ himii I himicheskoy tehnologii rastitelnogo syirya: materialyi III Vserosiyskoy konferencii, Barnaul, 1, pp. 20-24.

19. Barabash V.A., Primakov S.P., Trembus I.V., Kulik M.O. (2010), Modified ASAE method of wheat straw delignification, Himichna ingheneriya, ekologiya ta resursozberegennya, 2 , p. 4-6.

20. Obolenskaya A.V., Elnitskaya Z.P., Leonovich A.A. (1991), Laboratory research on wood and cellulose chemistry, Ekologiya, Moscow.

21. Korolkov I.I. (1990), Perkolyatsionnyi gidroliz rastitelnogo syirya, Lesnaya promyishlennost, Moscow.

22. Sinitsyin A.P., Gusakov A.V., Chernoglazov V.M. (1995), Biokonversiya lignoceluloznyih materialov, Moscow.

23. Vandenbrink Joshua P., Hilten Roger N., Das K.C., Paterson Andrew H. (2012), Feltus Frank Alex Analysis of Crystallinity Index and Hydrolysis Rates in the Bioenergy Crop Sorghum bicolor, Bioenerg. Res., 5, pp. 387-397. 